\title{
Study focuses on genetic fallout of the bomb
}

\section{David Cyranoski, Tokyo}

Children born to survivors of the 1945 atomic blasts in Japan are to be the subjects of a new study investigating the long-term effects of the atomic bomb. The research, which gets under way this month, will track the onset of diseases such as heart disease and diabetes, which are unlikely to show up until adulthood.

The work will be done by the Radiation Effects Research Foundation (RERF), a nonprofit private foundation funded jointly by the United States and Japan. RERF has laboratories in Hiroshima and Nagasaki - the two cities bombed with nuclear devices in 1945 by the United States.

To date, RERF has found no long-term genetic effects in the so-called $\mathrm{F}_{1}$ population, the roughly 80,000 children born to survivors of the US attacks between 1946 and 1984. But this result has surprised some researchers, as radiation has shown powerful genetic effects in animal experiments.

One possible explanation could be the technical limitations of the studies themselves, says Seymour Abrahamson, a fruitfly geneticist from the University of WisconsinMadison who recently joined RERF as its research director. "We know a lot more now about genetic diseases," he says.

The only systematic clinical study on $\mathrm{F}_{1}$ children was carried out between 1948 and

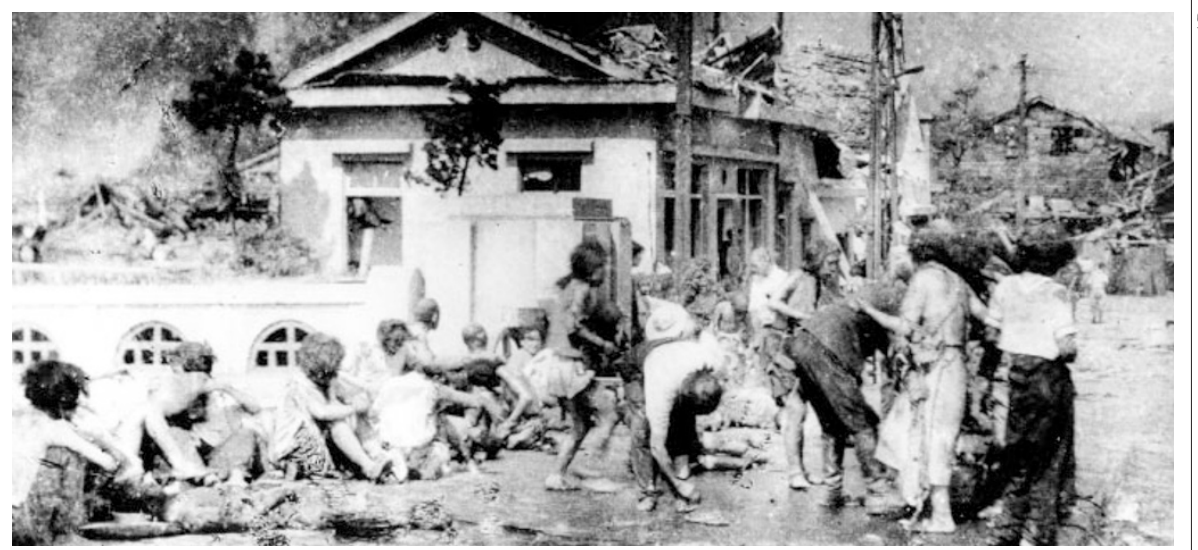

Survivors of Hiroshima: tracking their descendants will indicate genetic effects of nuclear war.

1953. Most of these were based on observations by doctors and midwives, who reported stillbirths and physically apparent abnormalities in children less than one year old.

Abrahamson says that there is still a possibility that radiation effects will show up as "late onset, multifactorial" genetic disorders not visible at infancy. "We have to close the circle," he says.

In January, RERF will conduct a postal survey of 20,000 people in the $F_{1}$ population to find out how many will be willing to undergo a full-scale clinical analysis. Data on health records and physical examinations will then be collected. It will probably take between four and six years for results from the analysis to appear, Abrahamson says.

But some of the study's potential subjects are opposed to the research because they fear that finding a genetic effect could lead to discrimination. Others, meanwhile, hope that a link between radiation and ill-health could justify their demands for benefits from the government. Only this year, Japanese courts awarded compensation from the government to plaintiffs who claimed that their illnesses were caused by the 1945 bombing. "This study is likely to influence such court decisions in the future," Abrahamson says.

| http://www.rerf.or.jp/eigo/experhp/rerfhome.htm

\section{Parliament gives green light to stem-cell research}

\section{David Dickson, London}

British scientists reacted with surprise and relief to a substantial vote of confidence from the House of Commons - the lower house of the UK parliament - over the use of human embryos for research into therapies for serious diseases.

Members of Parliament (MPs) agreed by 366 to 174 on 19 December to approve changes to the Human Fertilization and Embryology Act of 1990 allowing such research to take place.

"I was very surprised; we were expecting it to be much closer," says Austin Smith, director of the Centre for Genome Research at the University of Edinburgh, who already holds a licence for carrying out research on human embryos up to 14 days old as permitted by the 1990 act - but is currently restricted to work that is directed at problems of infertility.

Smith, one of the leading UK investigators in stem-cell research, says that a change in the regulations would not have any short-term impact on his research, apart from enabling him to obtain a broader licence. But it would make it possible for him to start work towards potential therapies, perhaps in neurodegenerative diseases such as Parkinson's and Alzheimer's disease.

The proposed change in the legislation had been strongly opposed both by antiabortion groups and prominent Roman Catholic leaders. Other opponents warned that the interest on obtaining stem cells from human embryos represents the beginning of a "slippery slope" towards human cloning.

Such arguments had been countered by a vigorous lobbying campaign by the scientific and medical establishment, with MPs being given briefings by, among others, the Royal Society, the Wellcome Trust and the Nuffield Council on Bioethics. The objections were also rejected last summer by a panel set up under the government's chief medical officer, Liam Donaldson (see Nature 406, 815; 2000).

But the most telling contributions to the debate perhaps came from several MPs who told of their personal battles with illness,

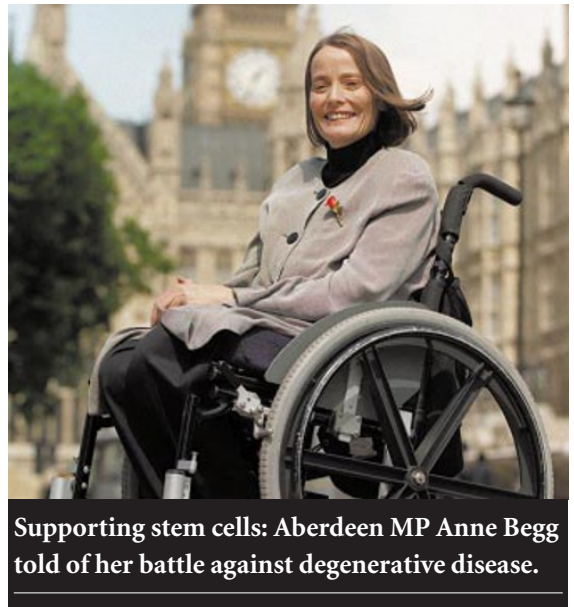

including Anne Begg (Labour, Aberdeen South) who suffers from a degenerative brittle-bone disease and is confined to a wheelchair.

The proposed change will next be debated in the House of Lords on 16 January, but, given the size of the Commons majority, researchers are optimistic that the Lords might not reject the measure. 